International Journal of Engineering \& Technology, $7(2.27)(2018)$ 199-204
International Journal of Engineering \& Technology
Website: $w$ ww.sciencepubco.com/index.php/IJET
Research paper

\title{
Design of library application system
}

\author{
Wulandari ${ }^{1}$, Sudirman Aminin ${ }^{2}$, M. Ihsan Dacholfany ${ }^{2}$, Abdul Mujib ${ }^{3}$, Miftachul Huda ${ }^{4}$, \\ Badlihisham Mohd Nasir ${ }^{4}$, Andino Maseleno ${ }^{1,5 *}$, Eni Sundari ${ }^{1}$, Fauzi ${ }^{1}$, M. Masrur ${ }^{1}$ \\ ${ }^{I}$ STMIK Pringsewu, Lampung, Indonesia \\ ${ }^{2}$ Universitas Muhammadiyah Metro, Lampung, Indonesia \\ ${ }^{3}$ State Islamic Institute of Metro, Lampung, Indonesia \\ ${ }^{4}$ Universiti Teknologi Malaysia, Malaysia \\ ${ }^{5}$ Institute of Informatics and Computing Energy, Universiti Tenaga Nasional, Malaysia \\ *Corresponding author E-mail: andimaseleno@gmail.com
}

\begin{abstract}
Library application is a computer program designed specifically to manage the data of borrowing and returning books in order to be presented more quickly. In addition, for the achievement of the purpose of the operation itself is to facilitate students by providing facilities. In making this application there were some important data such as Member data, Books, Transactions, and Admin. From the data were expected to be the basis made for this application in order to present the information needed quickly and precisely, and to improve the performance of librarians. Requirements as a member of the library is a Student of SMP Negeri 1 Talangpadang, then create a regis tration form to become a member of SMP Negeri 1 Talangpadang Students. The expected result of making this system was that the data that had been stored and managed manually can begin to be computerized so as to further advance the performance and facilitate librarians in carrying out activities related to the library itself.
\end{abstract}

Keywords: Student; Library; Application; School.

\section{Introduction}

The world of education is inseparable from reading. By reading, we can get very useful information, both from education, health, information from domestic and abroad. If student never wants to read it is certain the knowledge will not be perfect because reading is a window to open a new world.

Based on papers [1-54], in this globalization era where the advancement of information and communication technology (ICT) is growing rapidly and the utilization of IT (Information technology) in the field of education is already a natural thing. Therefore, many schools today are competing to advance the quality and quality for better education quality. Therefore, SMP Negeri 1 Talangpadang is demanded to improve the effectiveness in learning, one of them by making the visual basic-based application system of borrowing and returning books in the library of SMP Negeri 1 Talangpadang. In the processing of library borrowing data that is done manually it will make mistakes to the data and fatal mistakes due to data processing which is done manually and will slow down the working process of librarian. Therefore, the author took the initiative to create a Visual Basic 6.0 based library applications.

\subsection{Background}

In SMP Negeri 1 Talangpadang, the process of borrowing and returning books is still done manually by using a book of borrowing and returning that must be recorded. So the problems that is often happened such as writing the date of borrowing and returning book which spend a lot of paper and need data storage space members, calculation less accurate, and reporting takes a long time.

\subsection{Problem formulation}

The problem discussed in this research was how to build library application system in SMP Negeri 1 Talangpadang using Visual Basic 6.0.

\subsection{Problem limitation}

1) This application is only used in SMP Negeri 1 Talangpadang.

2) Member registration

3) Input applicant data.

4) The process for inputing new book data.

\subsection{Purpose}

The purposes of this research were:

1) Availability of Borrowing and Returning book application system in SMP Negeri 1 Talangpadang library to ease library data processing.

2) Accelerating of working process finishing

3) Simplifying implementation of work

4) Improve the quality of working result

5) Improving the efficiency and effectiveness of work

6) Generating library application system in SMP Negeri 1 Talangpadang

7) Simplifying information delivery to the member. 


\subsection{Benefit}

1) Improving effectiveness and efficiency in data processing of borrowing and returning book.

2) Simplifying member data, book data and transaction data

3) Accelerating process in making report.

4) Improving data safe.

5) It can reduce the similar data input

\section{Planning analysis and implementation}

a) Analysis

Needs collection process is done intensively to specify the software requirements to be understood software as required by the user

b) Design

A multi-step process that focuses on the design of programming software include data structures, software architectures, interface representation, and coding procedures.

c) Developing Program Code

The design should be translated into software program. The result of this stage is the computer program in accordance with the design that has been made at the design stage

d) Testing

This test focuses on the software in terms of logical and functional and ensures that all parts have been tested.

1) Context Diagram

Context diagram is a diagram that consists of a process and illustrate scope of a system. Context diagram is the highest level of DFD that configuring all inputs to the system or output of the system. It will give illustration to the whole system. The system is bounded by the boundary (can be figured with broken lines). In the context diagram there is only one process. There should be no store in the context diagram. The context diagram contains the general illustration (outline) of the system to be created. In a sentence, it can be said that this context diagram contains "anyone who gives data (and any data) to the system, as well as to anyone information (and any information) that the system should generate." So, what is needed are : (1) Anybody who will provide data to the system, (2) What data give to the system, (3) to whom the system should provide information or reports, and (4) what kind of content / type of report should the system produce

2) DFD

Data Flow Diagram (DFD) is a diagram that uses notations for illustrating flow of system data, whose use is helpful to understand the system logically, structured and clear. DFD is a tool in illustrating or explaining the work process of a system.

3) ERD

ERD is a model to explain the relationship between data in the database based on the basic objects of data that have relationships between relations. ERD to model the data structure and relationships between data, to illustrate that used some notations and symbols.

a) Entity

Entity is an object that represents something real and can be distinguished from something else. The symbol of this entity is usually illustrated with a rectangle.

b) Attribute

Each entity must has an element called an attribute that works to describe the characteristics of the entity. The contents of the attribute have something that can identify the contents of each element with another. Attributes figure is represented by ellipse symbols.

c) Relation

The relation between a number of entities derived from different entity sets. Relationships can be figured as follows: Relationships between two entity sets (eg A and B) in one database.

4) Implementaltion

To implement the design of this application program, then it is needed a tool in the form of a computer, where to operate the computer itself also requires three supporting components of hardware, software, brainware

\section{Form design}

\subsection{Main menu form}

Figure 1 shows main menu form

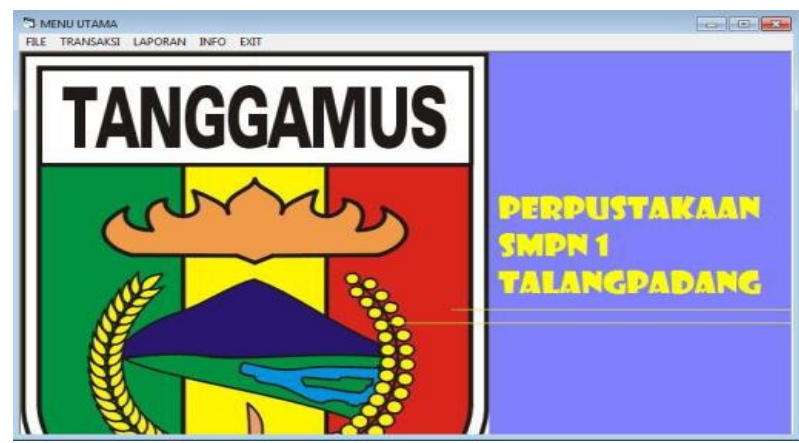

Fig. 1: Main Menu Form.

\subsection{Entry form for book data}

Figure 2 shows entry form for book data

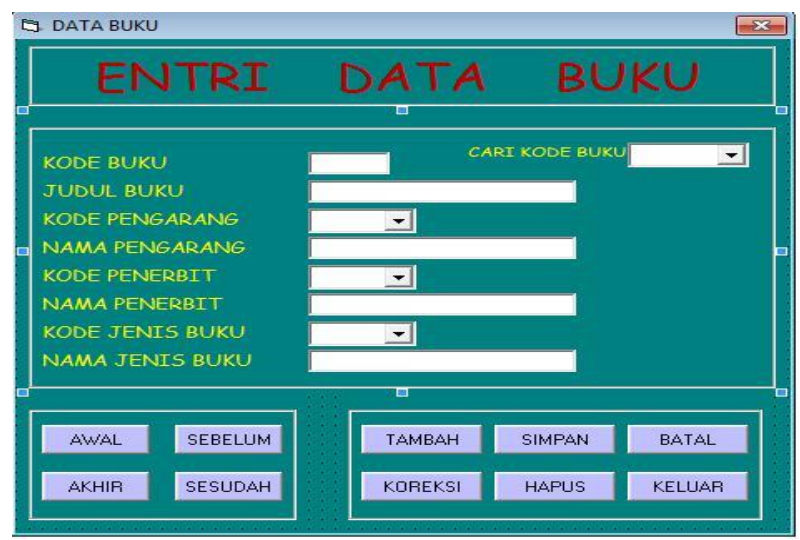

Fig. 2: Entry Form for Book Data

\subsection{Book returning form}

Figure 3 shows book returning form.

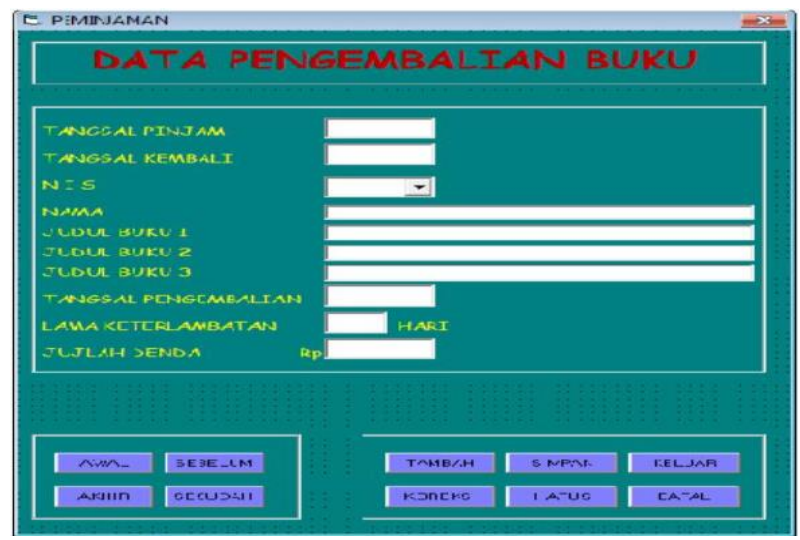

Fig. 3: Figure Book Returning Form.

\subsection{Book borrowing form}

Figure 4 shows book borrowing form 


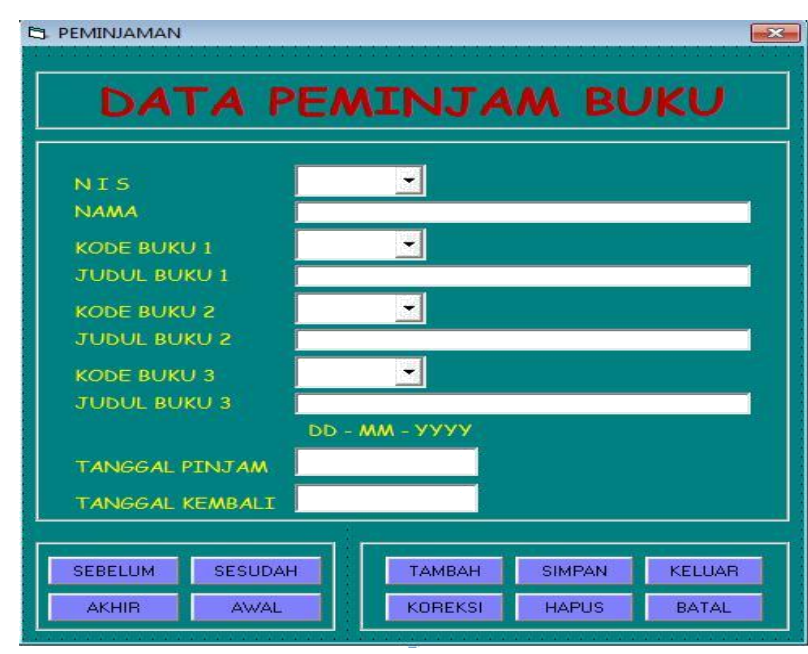

Fig. 4: Book Borrowing Form.

\subsection{Student data entry form}

Figure 5 shows tudent data entry form.

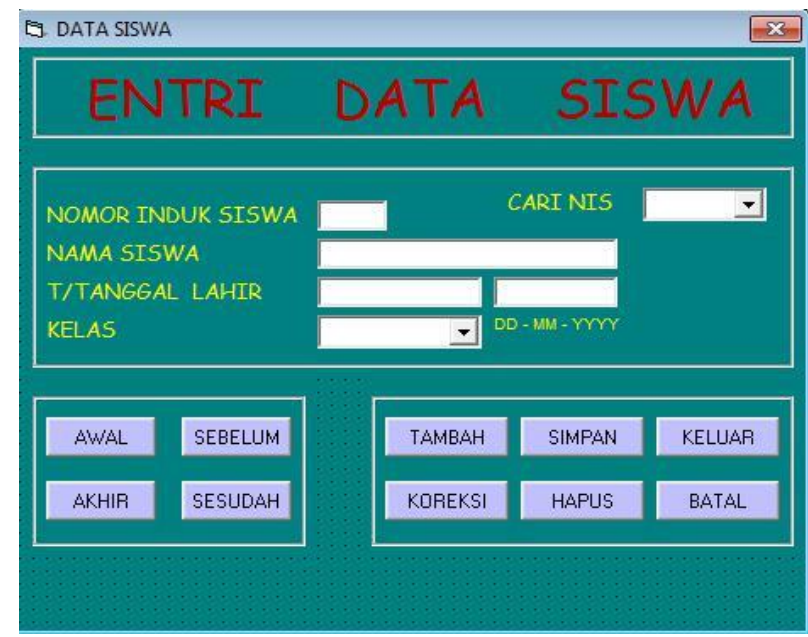

Fig. 5: Student Data Entry Form.

\subsection{Book type entry form}

Figure 6 shows Book type entry form.

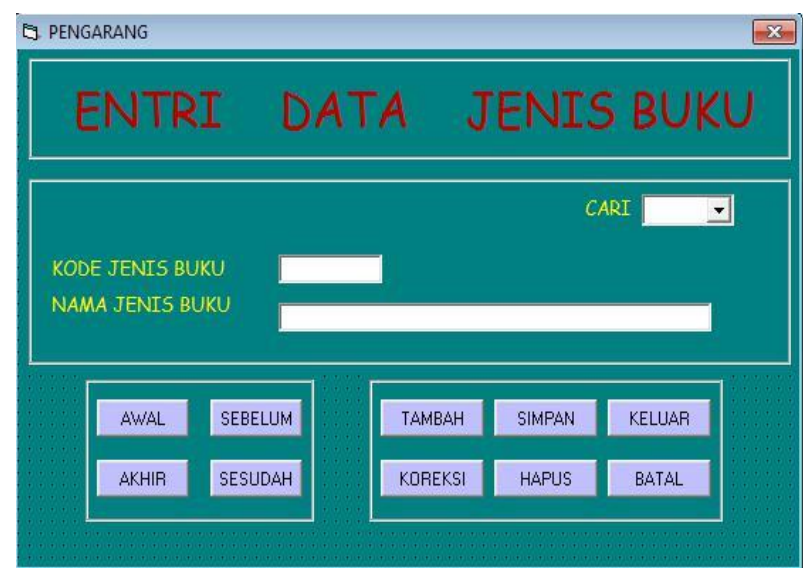

Fig. 6: Book Type Entry Form.

\subsection{Book data report book}

Figure 7 shows book data report book.

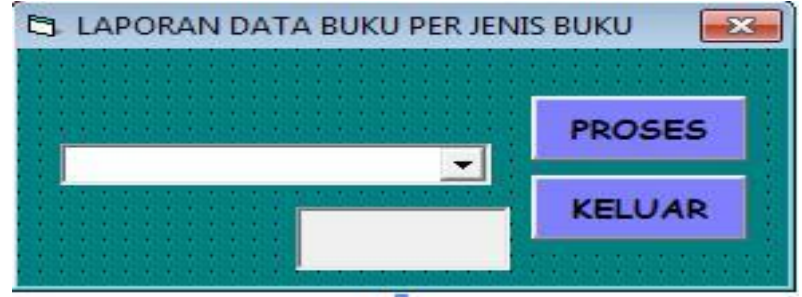

Fig. 7: Book Data Report Book.

\subsection{Student data report}

Figure 8 shows student data report.

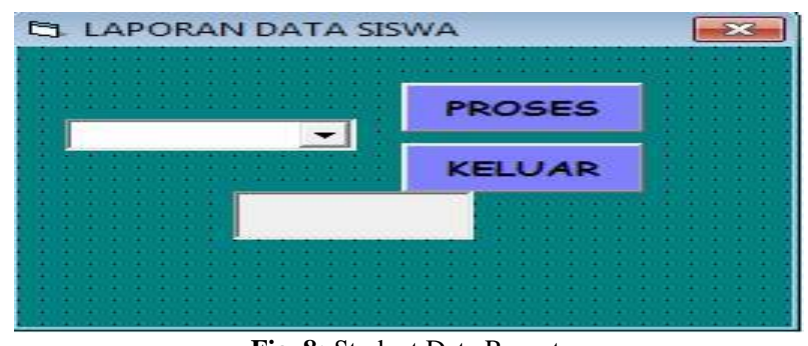

Fig. 8: Student Data Report.

\subsection{Book returning report}

Figure 9 shows book returning report.

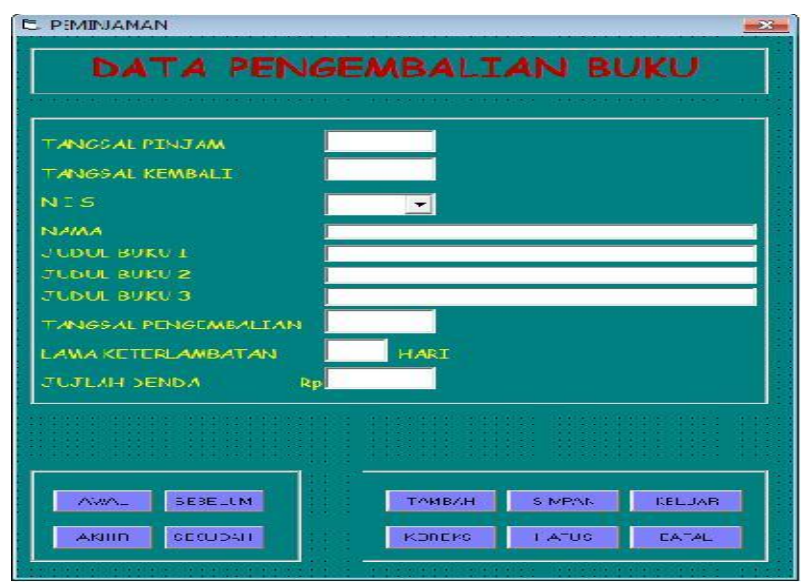

Fig. 9: Book Returning Report.

\subsection{Borrowing report form}

Figure 10 shows borrowing report form.

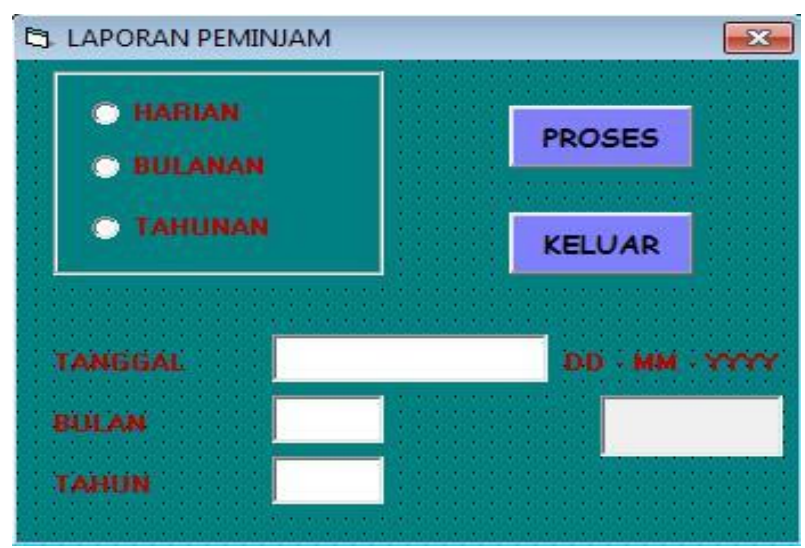

Fig. 10: Borrowing Report Form.

\subsection{Publisher data entry form}

Figure 11 shows publisher data entry form. 


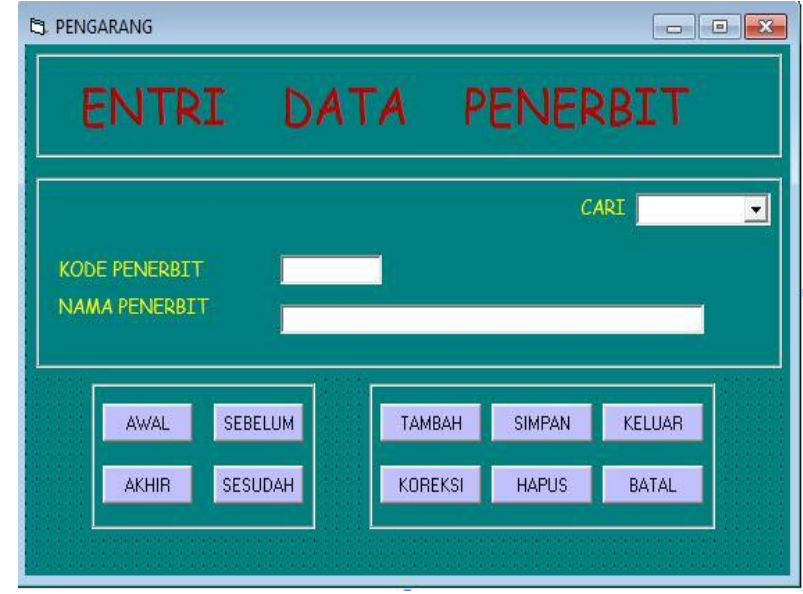

Fig. 11: Publisher Data Entry Form.

\subsection{Author data entry form}

Figure 12 shows author data entry form.

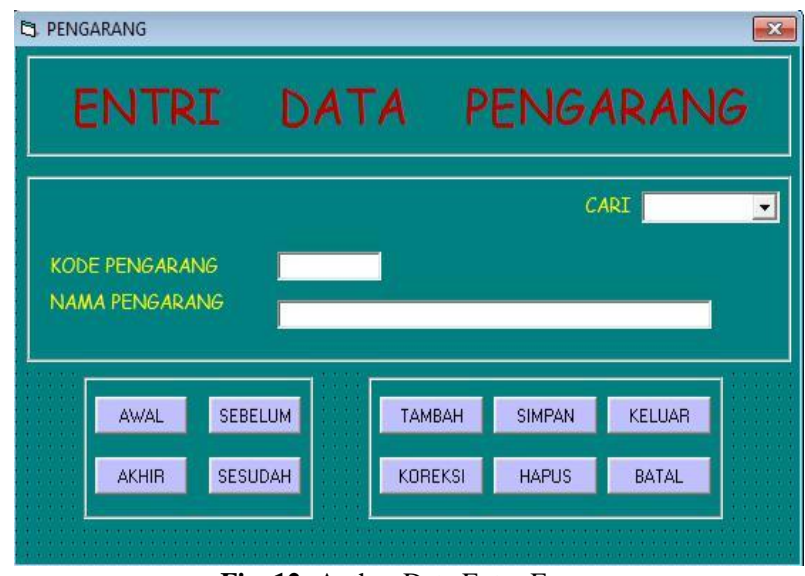

Fig. 12: Author Data Entry Form.

\section{Conclusion}

Based on the analysis that has been done by the authors of the problems on the SMP 1 Talangpadang library, it can be concluded the conclusion namely: 1) This application can streamline storage media and improve data security because all data are stored in database storage media. 2) This application can shorten the time in making member data reports, borrowing and returning book reports, and fines so that the report can be received by the principal on time.

The authors give some suggestions to SMP Negeri 1 Talangpadang namely: 1) This application is expected can be implemented by SMP Negeri 1 Talangpadang. 2) It is expected of holding training to librarians that have associated with this application to make this application run well as needed. 3) It is expected to perform routine maintenance of this app. 4) It is realized that the need for more comprehensive information is an important thing for business entities, namely to increase the business of borrowing and returning library books at SMP Negeri 1 Talangpadang, in achieving the results that have been planned, based on the above and also the limitations of this application, then is expected to further researchers to be able to improve this application.

\section{References}

[1] Adela, H., Jasmi, K.A., Basiron, B., Huda, M., Maseleno, A. (2018). Selection of dancer member using simple additive weighting. International Journal of Engineering \& Technology. 7(3). 1096-1107. https://doi.org/10.14419/ijet.v7i3.11983.

[2] Aminin, S., Huda, M., Ninsiana, W., and Dacholfany, M.I. (2018) Sustaining civic-based moral values: Insights from language learn- ing and literature. International Journal of Civil Engineering and Technology. 9(4), 157-174.

[3] Amin, M.M., Nugratama, M.A.A., Maseleno, A., Huda, M., Jasmi, K.A., (2018). Design of cigarette disposal blower and automatic freshner using mq-5 sensor based on atmega 8535 microcontroller. International Journal of Engineering \& Technology. 7(3). 11081113 https://doi.org/10.14419/ijet.v7i3.11917.

[4] Atmotiyoso, P. and Huda, M. (2018). Investigating Factors Influencing Work Performance on Mathematics Teaching: A Case Study. International Journal of Instruction. 11(3), 391-402. https://doi.org/10.12973/iji.2018.11327a.

[5] Huda, M., \& Teh, K. S. M. (2018). Empowering Professional and Ethical Competence on Reflective Teaching Practice in Digital Era. In Dikilitas, K., Mede, E., Atay D. (Eds). Mentorship Strategies in Teacher Education (pp. 136-152). Hershey, PA: IGI Global. doi: 10.4018/978-1-5225-4050-2.ch007 https://doi.org/10.4018/978-15225-4050-2.ch007.

[6] Huda, M., Teh, K.S.M., Nor, N.H.M., and nor, M.B.M. (2018a). Transmitting Leadership Based Civic Responsibility: Insights from Service Learning. International Journal of Ethics and Systems, 34(1), 20-31. https://doi.org/10.1108/IJOES-05-2017-0079.

[7] Huda, M., Maseleno, A., Muhamad, N.H.N., Jasmi, K.A., Ahmad, A., Mustari, M.I., Basiron, B. (2018b). Big Data Emerging Technology: Insights into Innovative Environment for Online Learning Resources. International Journal of Emerging Technologies in Learning 13(1), 23-36. https://doi.org/10.3991/ijet.v13i01.6990.

[8] Huda, M., Maseleno, A., Teh, K.S.M., Don, A.G., Basiron, B., Jasmi, K.A., Mustari, M.I., Nasir, B.M., and Ahmad, R. (2018c). Understanding Modern Learning Environment (MLE) in Big Data Era. International Journal of Emerging Technologies in Learning. 13(5), 71-85. https://doi.org/10.3991/ijet.v13i05.8042.

[9] Huda, M. (2018b). Empowering Application Strategy in the Technology Adoption: Insights from Professional and Ethical Engagement. Journal of Science and Technology Policy Management. doi.org/10.1108/JSTPM-09-2017-0044.

[10] Huda. M. \& Sabani, N. (2018). Empowering Muslim Children's Spirituality in Malay Archipelago: Integration between National Philosophical Foundations and Tawakkul (Trust in God). International Journal of Children's Spirituality, 23(1), 81-94. https://doi.org/10.1080/1364436X.2018.1431613.

[11] Huda, M., Qodriah, S.L., Rismayadi, B., Hananto, A., Kardiyati, E.N., Ruskam, A., and Nasir, B.M. (2018). Towards Cooperative with Competitive Alliance: Insights into Performance Value in Social Entrepreneurship in Creating Business Value and Competitive Advantage with Social Entrepreneurship. (pp.294). Hershey, PA: IGI Global.

[12] Huda, M., Hehsan, A., Basuki, S., Rismayadi, B., Jasmi, K. A., Basiron, B., \& Mustari, M. I. (2019). Empowering Technology Use to Promote Virtual Violence Prevention in Higher Education Context. In Intimacy and Developing Personal Relationships in the Virtual World (pp. 272-291). Hershey, PA: IGI Global. https://doi.org/10.4018/978-1-5225-4047-2.ch015.

[13] Huda, M., Ulfatmi, Luthfi, M.J., Jasmi, K.A., Basiron, B., Mustari, M.I., Safar, A., Embong, H.W.H., Mohamad, A.M., and Mohamed, A.K. (2019). Adaptive online learning technology: Trends in big data era in Diverse Learning Opportunities Through TechnologyBased Curriculum Design. Hershey, PA: IGI Global. (In press).

[14] Kurniasih, D., Jasmi, K.A., Basiron, B., Huda, M., Maseleno, A. (2018). The uses of fuzzy logic method for finding agriculture and livestock value of potential village. International Journal of Engi$\begin{array}{llll}\text { neering } \quad \text { \& } \quad \text { Technology. } & \text { 7(3). 1091-1095. }\end{array}$ https://doi.org/10.14419/ijet.v7i3.11984.

[15] Maseleno, A., Pardimin, Huda, M., Ramlan, Hehsan, A., Yusof, Y.M., Haron, Z., Ripin, M.N., nor, N.H.M., and Junaidi, J. (2018a). Mathematical Theory of Evidence to Subject Expertise Diagnostic. ICIC Express Letters, 12 (4), 369 DOI: 10.24507/icicel.12.04.369

[16] Maseleno, A., Huda, M., Jasmi, K.A., Basiron, B., Mustari, I., Don, A.G., and Ahmad, R. (2018b). Hau-Kashyap approach for student's level of expertise. Egyptian Informatics Journal, https://doi.org/10.1016/j.eij.2018.04.001.

[17] Maseleno, A., Sabani, N., Huda, M., Ahmad, R., Jasmi, K.A., Basiron, B. (2018c). Demystifying Learning Analytics in Personalised Learning. International Journal of Engineering \& Technology. 7(3). 1124-1129. https://doi.org/10.14419/ijet.v7i3.9789.

[18] Moksin, A. I., Shahrill, M., Anshari, M., Huda, M., \& Tengah, K. A (2018b). The Learning of Integration in Calculus Using the Autograph Technology. Advanced Science Letters, 24(1), 550-552. https://doi.org/10.1166/asl.2018.12067.

[19] Putra, D.A.D., Jasmi, K.A., Basiron, B., Huda, M., Maseleno, A., Shankar, K., Aminudin, N. (2018). Tactical Steps for E- 
Government Development. International Journal of Pure and Applied Mathematics. 119 (15). 2251-2258

[20] Rosli, M.R.B., Salamon, H.B., and Huda, M. (2018). Distribution Management of Zakat Fund: Recommended Proposal for Asnaf Riqab in Malaysia. International Journal of Civil Engineering and Technology 9(3), pp. 56-64.

[21] Sugiyarti, E., Jasmi, K.A., Basiron, B., Huda, M., Shankar, K., Maseleno, A. (2018). Decision support system of scholarship grantee selection using data mining. International Journal of Pure and Applied Mathematics.119 (15), 2239-2249.

[22] Sundari, E., Aminin, S., Dacholfany, M.I., Mujib, A., Huda, M. Nasir, B.M., and Maseleno, A. (2018). Web-Based Decision Making System for Assessment of Employee Revenue Using Weighted Product. International Journal of Engineering and Technology (In Press).

[23] Susilowati, T., Jasmi, K.A., Basiron, B., Huda, M., Shankar, K. Maseleno, A., Julia, A., Sucipto. (2018). Determination of Scholarship Recipients Using Simple Additive Weighting Method. International Journal of Pure and Applied Mathematics.119 (15), 22312238.

[24] Anshari, M., Almunawar, M. N., Shahrill, M., Wicaksono, D. K., \& Huda, M. (2017). Smartphones usage in the classrooms: Learning aid or interference. Education and Information Technologies, 22(6), 3063-3079. https://doi.org/10.1007/s10639-017-9572-7.

[25] Huda, M., Sabani, N., Shahrill, M., Jasmi, K. A., Basiron, B., \& Mustari, M. I. (2017a). Empowering Learning Culture as Student Identity Construction in Higher Education. In A. Shahriar, \& G. Syed (Eds.), Student Culture and Identity in Higher Education (pp. 160-179). Hershey, PA: IGI Global. https://doi.org/10.4018/978-15225-2551-6.ch010.

[26] Huda, M., Jasmi, K. A., Hehsan, A., Shahrill, M., Mustari, M. I., Basiron, B., \& Gassama, S. K. (2017b). Empowering Children with Adaptive Technology Skills: Careful Engagement in the Digital Information Age. International Electronic Journal of Elementary Education, 9(3), 693-708.

[27] Huda, M., Shahrill, M., Maseleno, A., Jasmi, K. A., Mustari, I., \& and Basiron, B. (2017c). Exploring Adaptive Teaching Competencies in Big Data Era. International Journal of Emerging Technologies in Learning, 12(3), 68-83. https://doi.org/10.3991/ijet.v12i03.6434.

[28] Huda, M., Jasmi, K. A., Basiran, B., Mustari, M. I. B., \& Sabani, A. N. (2017d). Traditional Wisdom on Sustainable Learning: An Insightful View From Al-Zarnuji's Ta 'lim al-Muta 'allim. SAGE Open, 7(1), 1-8. https://doi.org/10.1177/2158244017697160.

[29] Huda, M., Jasmi, K. A., Embong, W. H., Safar, J., Mohamad, A. M., Mohamed, A. K., Muhamad, N. H., Alas, Y., \& Rahman, S. K. (2017e). Nurturing Compassion-Based Empathy: Innovative Approach in Higher Education. In M. Badea, \& M. Suditu (Eds.), Violence Prevention and Safety Promotion in Higher Education Settings (pp. 154-173). Hershey, PA: IGI Global. https://doi.org/10.4018/978-1-5225-2960-6.ch009.

[30] Huda, M., Jasmi, K. A., Alas, Y., Qodriah, S. L., Dacholfany, M. I., \& Jamsari, E. A. (2017f). Empowering Civic Responsibility: Insights From Service Learning. In S. Burton (Ed.), Engaged Scholarship and Civic Responsibility in Higher Education(pp. 144165). Hershey, PA: IGI Global. https://doi.org/10.4018/978-1-52253649-9.ch007.

[31] Huda, M., Jasmi, K. A., Mustari, M. I., Basiron, B., Mohamed, A. K., Embong, W., ... \& Safar, J. (2017g). Innovative E-Therapy Service in Higher Education: Mobile Application Design. International Journal of Interactive Mobile Technologies, 11(4), 83-94. https://doi.org/10.3991/ijim.v11i4.6734.

[32] Huda, M., Jasmi, K. A., Mustari, M. I., \& Basiron, B. (2017h) Understanding Divine Pedagogy in Teacher Education: Insights from Al-zarnuji's Ta'lim Al-Muta'Allim. The Social Sciences, 12(4), 674-679.

[33] Huda, M., Jasmi, K. A., Mustari, M. I. B., \& Basiron, A. B. (2017i) Understanding of Wara' (Godliness) as a Feature of Character and Religious Education. The Social Sciences, 12(6), 1106-1111.

[34] Huda, M., Siregar, M., Ramlan, Rahman, S.K.A., Mat Teh, K.S., Said, H., Jamsari, E.A., Yacub, J., Dacholfany, M.I., \& Ninsiana, W. (2017j). From Live Interaction to Virtual Interaction: An Exposure on the Moral Engagement in the Digital Era. Journal of Theoretical and Applied Information Technology , 95(19), 49644972

[35] Huda, M., Maseleno, A., Jasmi, K. A., Mustari, I., \& Basiron, B. (2017k). Strengthening Interaction from Direct to Virtual Basis: Insights from Ethical and Professional Empowerment. International Journal of Applied Engineering Research, 12(17), 6901-6909.
[36] Huda, M., Haron, Z., Ripin, M. N., Hehsan, A., \& Yaacob, A. B. C. (20171). Exploring Innovative Learning Environment (ILE): Big Data Era. International Journal of Applied Engineering Research, 12(17), 6678-6685.

[37] Maseleno, A., Huda, M., Siregar, M., Ahmad, R., Hehsan, A., Haron, Z., Ripin, M.N., Ihwani, S.S., and Jasmi, K.A. (2017). Combining the Previous Measure of Evidence to Educational Entrance Examination. Journal of Artificial Intelligence 10(3), 8590. https://doi.org/10.3923/jai.2017.85.90.

[38] Huda, M., Yusuf, J. B., Jasmi, K. A., \& Nasir, G. A. (2016b). Understanding Comprehensive Learning Requirements in the Light of al-Zarnūjī's Ta‘'īm al-Muta'allim. Sage Open, 6(4), 1-14. https://doi.org/10.1177/2158244016670197.

[39] Huda, M., Yusuf, J. B., Jasmi, K. A., \& Zakaria, G. N. (2016c). AlZarnūjī's Concept of Knowledge ('ilm). SAGE Open, 6(3), 1-13. https://doi.org/10.1177/2158244016666885.

[40] Huda, M., Jasmi, K. A., Mohamed, A. K., Wan Embong, W. H., \& and Safar, J. (2016d). Philosophical Investigation of Al-Zarnuji's Ta'lim al-Muta'allim: Strengthening Ethical Engagement into Teaching and Learning. Social Science, 11(22), 5516-551.

[41] Kartanegara, M., \& Huda, M. (2016). Constructing Civil Society: An Islamic Cultural Perspective. Mediterranean Journal of Social Science, 7(1), 126-135.

[42] Othman, R., Shahrill, M., Mundia, L., Tan, A., \& Huda, M. (2016). Investigating the Relationship between the Student's Ability and Learning Preferences: Evidence from Year 7 Mathematics Students. The New Educational Review, 44(2), 125-138.

[43] Huda, M., Anshari, M., Almunawar, M. N., Shahrill, M., Tan, A., Jaidin, J. H., \& Masri, M. (2016a). Innovative Teaching in Higher Education: The Big Data Approach. The Turkish Online Journal of Educational Technology, 15(Special issue), 1210-1216.

[44] Susilowati, T., Teh, K.S.T., Nasir, B.M., Don, A.G., Huda, M., Hensafitri, T., Maseleno, A., Oktafianto, Irawan, D. Learning Application of Lampung Language Based on Multimedia Software. International Journal of Engineering and Technology (UAE) (In Press).

[45] Abadi, S., Teh, K.S.M., Nasir, B.M., Huda, M., Ivanova, N.L., Sari, T.I., Maseleno, A., Satria, F., Muslihudin, M. Application Model of K-Means Clustering Insights into Promotion Strategy of Vocational High School. International Journal of Engineering and Technology (UAE) (In Press)

[46] Susilowati, T., Dacholfany, M.I., Aminin, S., Ikhwan, A., Nasir, B.M., Huda, M., Prasetyo, A., Maseleno, A., Satria, F., Hartati, S., Wulandari. Getting Parents Involved in Child's School: Using Attendance Application System Based on SMS Gateway. International Journal of Engineering and Technology (UAE) (In Press).

[47] Aminudin, N., Huda, M., Ihwani, S.S., Noor, S.S.M., Basiron, B., Jasmi, K.A., Safar, J., Mohamed, A.K., Embong, W.H.W., Mohamad, A.M., Maseleno, A., Masrur, M., Trisnawati, Rohmadi, D. The Family Hope Program using AHP Method. International Journal of Engineering and Technology (UAE) (In Press).

[48] Aminudin, N., Fauzi, Huda, M., Hehsan, A., Ripin, M.N., Haron, Z., Junaidi, J., Irviani, R., Muslihudin, M., Hidayat, S., Maseleno, A., Gumanti, M., Fauzi, A. Application Program Learning Based on Android for Students' Experiences. International Journal of Engineering and Technology (UAE) (In Press).

[49] Abadi, S., Teh, K.S.M., Huda, M., Hehsan, A., Ripin, M.N., Haron, Z., Muhamad, N.H.N., Rianto, R., Maseleno, A., Renaldo, R., Syarifudin, A. Design of student score application for assessing the most outstanding student at vocational high school. International Journal of Engineering and Technology (UAE) (In Press).

[50] Aminudin, N., Huda, M., Kilani, A., Embong, W.H.W., Mohamed, A.M., Basiron, B., Ihwani, S.S., Noor, S.S.M., Jasmi, K.A., Safar, J., Ivanova, N.L., Maseleno, A., Triono, A., Nungsiati. Higher Education Selection using Simple Additive Weighting. International Journal of Engineering and Technology (UAE) (In Press).

[51] Anggraeni, E.Y., Huda, M., Maseleno, A., Safar, J., Jasmi, K.A., Mohamed, A.K., Hehsan, A., Basiron, B., Ihwani, S.S., Embong, W.H.W., Mohamad, A.M., Noor, S.S.M., Fauzi, A., Wijaya, D.A., Masrur, M. Poverty Level Grouping using SAW Method. International Journal of Engineering and Technology (UAE) (In Press).

[52] Abadi, S., Huda, M., Jasmi, K.A., Noor, S.S.M., Safar, J., Mohamed, A.K., Embong, W.H.W., Mohamad, A.M., Hehsan, A., Basiron, B., Ihwani, S.S., Maseleno, A., Muslihudin, M., Satria, F., Irawan, D., Hartati, S. Determination of the Best Quail Eggs using Simple Additive Weighting. International Journal of Engineering and Technology (UAE) (In Press).

[53] Abadi, S., Huda, M., Hehsan, A., Mohamad, A.M., Basiron, B., Ihwani, S.S., Jasmi, K.A., Safar, J., Mohamed, A.K., Embong, W.H.W., Noor, S.S.M., Brahmono, B., Maseleno, A., Fauzi, A., 
Aminudin, N., Gumanti, M. Design of online transaction model on traditional industry in order to increase turnover and benefits. Inter national Journal of Engineering and Technology (UAE) (In Press).

[54] Abadi, S., Huda, M., Basiron, B., Ihwani, S.S., Jasmi, K.A., Hehsan, A., Safar, J., Mohamed, A.K., Embong, W.H.W., Mohamad, A.M. Noor, S.S.M., Novita, D., Maseleno, A., Irviani, R., Idris, M., Muslihudin, M. Implementation of Fuzzy Analytical Hierarchy Process on Notebook Selection. International Journal of Engineering and Technology (UAE) (In Press). 